\title{
The Consequences of Terrorist and Military Operations in Three Regions of Baghdad, Iraq on Serotonin and Thyroid Function
}

\author{
Alaa H. Jawad \\ Department of Chemistry, College of Science, Al-Nahrain University, Baghdad-Iraq.
}

\begin{abstract}
In this paper the effect of terrorist and military operations in three regions of Baghdad, Iraq were studied on thyroid gland function and serotonin hormones, in 75 Iraqi individual from (AL-karradah and Abo-Gharib) regions as comparison with Al-jadria (control). The correlation between sera thyroid hormones thyroxine T4, triiodothyronine T3, thyrotropin TSH and serotonin have been indicated, the utilization of thyroid hormones as a compelling subordinate treatment for full of feeling issue has been contemplated in the course of recent decades and has been adjusted more than once. Communication of the thyroid and monoamine neurotransmitter frameworks has been recommended as a potential underline component of action. The serotonin framework has been moderately ignored, along these lines; the objective of this article is to audit the writing on the connection between thyroid hormones and the mind serotonin. Our examination proposes a negatively relationship between serotonin and thyroid stimulating hormones (TSH), a positive correlation between serotonin and thyroxine, while there were significant positive correlations between serotonin and triiodothyronine. In conclusion, there is powerful confirmation, that the thyroid economy has a balancing sway in the brain serotonin system, thus considerable further investigation will be necessary to understand the role of serotonin in the pathogenesis and high levels in the some regions in Iraq such as AL-karradah and Abo-Gharib.
\end{abstract}

[DOI: 10.22401/JNUS.21.2.05]

Keywords: Serotonin, thyroid hormones, T3, T4, TSH, pollution, Baghdad area.

\section{Introduction}

A focal factor recognizing psychological warfare from other significant sorts of viciousness or terrorizing is that it is generally centered by the culprits around particular high esteem targets, by its extremely nature, the harms from fear based oppression go past the prompt death toll, human wellbeing, air contamination and property, accordingly an investigation of the impacts of psychological warfare on ecological ailment, even if people are exposed to direct dangers, direct exposure to radiation, they may face or numbness Increment the danger of specific tumors, for example, leukemia and thyroid cancer, it has been destroyed the lives of a number of people are much greater than justified time $\left[^{1}\right]$. Fallujah and Basrah, two heavily bombarded cities, are both contaminated, the subsequent defilement is associated with causing a high number of genuine infections all through Iraq, incorporating ascends in inborn birth absconds, premature deliveries, premature births, infertility, leukemia, cancer and other illnesses not previously seen in Iraq..$^{[2]}$
The study of pollution is very important to keep human in health, pollutant is any substance affecting environmental through humanś actions that can have serious effects on the human body, dysfunction of enzymes and mechanical function of thyroid gland $\left[^{3}\right]$. Thyroid hormones affect the capacity of all tissues and influence basically every significant pathway, counting thermogenesis, sugar digestion, lipid homeostasis, development, advancement and direction of digestion and thermogenesis..$\left.^{4}\right]$ Thyroid organ produces three imperative metabolic hormones, thyroxine, tri-iodothyronine, and calcitonin. Thyrotropin (TSH) created by the front pituitary organ controls the generation of these hormones, (T4) and triiodothyronine (T3), are recognized by thyrotropin (TSH)..$\left.^{5}\right]$

Serotonin, or 5-hydroxytryptamine (5-HT), is an outstanding neurotransmitter that assumes imperative parts in neural exercises and social practices there is expanding proof exhibiting vital parts of serotonin in the fringe tissues, as a standout amongst the most established monoamine neurotransmitters and 
hormones in the focal sensory system and fringe tissues, serotonin (additionally called 5hydroxytryptamine [5-HT]) has been found for almost 70 years. $\left.{ }^{[6]}\right]$

Connection of the thyroid and monoamine neurotransmitter frameworks has been proposed as a potential basic work mechanism. In spite of the fact that the serotonin framework has been given noticeable quality in late consultation in regards to inclination adjustment, especially since the approach of medications that particularly meddle with serotonin neuronal reuptake frameworks, there has been little examination of the relationship of this framework to the thyroid framework, impacts of low versus high dosages of thyroid hormones on the serotonin framework a few examinations analyzed the impacts of a low (substitution) versus a high measurement of thyroid hormones on serotonin receptors. $\left[^{7}\right]$

This current examination's objective was to limit the known variables of blood serotonin and thyroid hormones, and the effect of terrorist and military operations on the thyroid function

\section{Materials and Methods}

The present study comprised of 75 individual (40 Female and 35 Male) no symptoms of thyroid disease and an individual must be non smoker and pregnant women's, patients with any endocrine disease were excluded. The studied groups were divided to three groups [namely Al-jadria group (control group) $(n=25)$, Al-karradah group $(n=25)$ AboGharib $(n=25)$, aged between 15-65 years. Blood samples were collected from individual in three hospitals, 1) Abdul mageed private hospital 2) Abu Ghraib General Hospital 3) Jadria Health Center, samples were hospitalized at laboratories in the Abdul mageed private hospital. The specimens were gathered from October 2016 to February 2017, blood sample were collected $(5 \mathrm{ml})$ and centrifuged at [4000 rpm] for $10 \mathrm{~min}$ after clotting, the blood serum were separated and stored at $[-20]^{\circ} \mathrm{C}$ until time of analyses, human serum thyroxine (T4), Thyrotropin (TSH), triiodothyronine (T3) and Serotonin were measured by (ELISA) an enzymes-linkedimmune-sorbents assay kits (Sandwich) technology for individual in three hospitals using commercially available kits T3, T4, $\mathrm{TSH}$, and serotonin (Human, Germany).

\section{Statistical Analysis}

Statistical analysis of results was performed utilizing (Statistical Analysis System-version 9.1). One-way ANOVA and Least significants difference (LSD) tests were performed to estimate significants differences among means. ( $P$ value $<0.05)$ was considered factually significants.

\section{Results and Discussion}

Table (1) shows the means, standard deviation, maximum and minimum levels of thyroxine (T4), Thyrotropin (TSH) triiodothyronine (T3), and serotonin (ST) for the three studied groups.

Results in Table (1) showed that the serum T3 and TSH levels were similar across each group $(P>0.05)$ but similar T4 compared to Al-Jadria controls. Comparison of thyroid hormones in pollutants areas (Al-karadah, Abo-Gharib) and controls are shown that T3 and TSH levels were not significant different between the both groups (Al-Karradah: T3 $(1.12 \pm 0.06 \mathrm{ng} / \mathrm{ml}$ vs. control: $1.12 \pm 0.03$ ng/mL, $\quad P=0.43) \quad$ respectively.; $\quad \mathrm{TSH}$ $(2.21 \pm 0.30 \mathrm{mIU} / \mathrm{l}$ vs. control: $1.97 \pm 0.22$ $\mathrm{mIU} / \mathrm{l}, P=0.42$ ) also shown that the T3 and TSH levels were not significant different between the both groups:T3 (Abo.Gharib: $1.27 \pm 0.07 \mathrm{ng} / \mathrm{ml}$ vs. control: $1.12 \pm 0.03 \mathrm{ng} / \mathrm{mL}$, $P=0.43)$. respectively; TSH $(2.05 \pm 0.25 \mathrm{mIU} / \mathrm{l}$ vs. control: $1.97 \pm 0.22 \mathrm{mIU} / \mathrm{l}, P=0.42)$.

Comparison of thyroid hormones in pollutants areas (Al-karadah, Abo-Gharib) and controls are shown that T4 Levels were significant statistically $(p<0.05)$, between the both groups Al-Karradah: T4 $(9.13 \pm 0.36 \mu \mathrm{g} / \mathrm{dl}$ vs. control: $8.43 \pm 0.37 \mu \mathrm{g} / \mathrm{dl}, P=0.045)$. Also shown that the T4 levels were significant statistically ( $p<0.05)$, between the both groups Abo.Gharib: T4 $(9.41 \pm 0.36 \mu \mathrm{g} / \mathrm{dl}$ vs. control: $8.43 \pm 0.37 \mu \mathrm{g} / \mathrm{dl}, P=0.045)$.

Comparison of serotonin in pollutants areas (Al-karadah, Abo-Gharib) and controls are shown that serotonin levels were significant statistically $(p<0.05)$, between the both groups Al-Karradah: ST $\quad(236.08 \pm 31.18 \mathrm{ng} / \mathrm{ml}$ vs. control: $109.00 \pm 13.14 \mathrm{ng} / \mathrm{mL}, P=0.023)$. Also shown 
that the serotonin levels were significant statistically $(p<0.05)$, between the both groups
Abo.Gharib: ST $\quad(186.55 \pm 36.51 \mathrm{ng} / \mathrm{ml} \quad$ vs. control: $109.00 \pm 13.14 \mathrm{ng} / \mathrm{mL}, P=0.023)$.

Table (1)

Mean values, standard error, (mean \pm standard error), maximum, minimum and standard deviation of T3, T4, ST and TSH levels in the human serum from three different hospitals in Baghdad.

\begin{tabular}{||c|l|l|l||l||}
\hline Region & TSH( mIU/l) & T3( ng/ml $)$ & \multicolumn{1}{|c|}{ T4 $(\boldsymbol{\mu g} / \mathbf{d l})$} & \multicolumn{1}{|c|}{ ST $(\mathbf{n g} / \mathbf{m L})$} \\
\hline \hline Al-Karadah & $2.21 \pm 0.30$ & $1.12 \pm 0.06$ & $9.13 \pm 0.36 \mathrm{a}$ & $236.08 \pm 31.18 \mathrm{a}$ \\
Min-Max & $(0.36-5.52)$ & $(0.84-2.62)$ & $(5.08-12.41)$ & $(50.80-547.40)$ \\
STD & 1.50 & 0.35 & 1.86 & 155.92 \\
\hline \hline Abo-Gharib & $2.05 \pm 0.25$ & $1.27 \pm 0.07$ & $9.41 \pm 0.36 \mathrm{a}$ & $186.55 \pm 36.51 \mathrm{~b}$ \\
Min-Max & $(0.41-6.08)$ & $(0.91-2.70)$ & $(5.55-13.50)$ & $(15.10-576.00)$ \\
STD & 1.31 & 0.43 & 1.88 & 182.58 \\
\hline Al-Jadria & $1.97 \pm 0.22$ & $1.12 \pm 0.03$ & $8.43 \pm 0.37 \mathrm{~b}$ & $109.00 \pm 13.14 \mathrm{c}$ \\
Min-Max & $(0.43-4.03)$ & $(0.92-2.02)$ & $(4.84-11.20)$ & $(14.70-274.60)$ \\
STD & 1.13 & 0.20 & 1.85 & 65.71 \\
\hline LSD & 0.7537 & 0.1983 & 0.9627 & 61.035 \\
\hline P & 0.42 & 0.43 & 0.045 & 0.023 \\
\hline
\end{tabular}

a,b,c: The difference letters in the same column means a significant difference in parameters between groups.

T3: Triiodothyronine/ T4: Thyroxine/ TSH: Thyrotropin/ ST: Serotonin

The associations of human serum T4, T3, TSH and ST were examined using correlation coefficients for each exposure-outcome association.

Table (2)

Correlation coefficients of the human serum serotonin in connection to thyroid hormones in Al-karadah.

\begin{tabular}{|c|c|c|c|c|c|}
\hline \multicolumn{2}{|r|}{ Al-karadah } & $\begin{array}{c}\text { Triiodothyronine } \\
\text { (ng/ml) }\end{array}$ & $\begin{array}{c}\text { Thyroxine } \\
(\mu \mathrm{g} / \mathrm{dl})\end{array}$ & $\begin{array}{c}\text { Thyrotropin } \\
\text { ( mIU/l) }\end{array}$ & $\begin{array}{c}\text { Serotonin } \\
(\mathrm{ng} / \mathrm{mL})\end{array}$ \\
\hline \multirow{2}{*}{ T3 } & Pearson Correlation & & -.701 & .142 & $.869^{*}$ \\
\hline & $\mathbf{P}$ & & .121 & .786 & .025 \\
\hline \multirow{2}{*}{$\mathbf{T 4}$} & Pearson Correlation & & & .143 & .644 \\
\hline & $\mathbf{P}$ & & & .785 & .167 \\
\hline \multirow{2}{*}{ TSH } & Pearson Correlation & & & & $\begin{array}{l}.071- \\
\end{array}$ \\
\hline & $\mathbf{P}$ & & & & .894 \\
\hline
\end{tabular}


Table (3)

Correlation coefficients of the human serum serotonin in relation to thyroid hormones in Abo-Gharib.

\begin{tabular}{|c|c|c|c|c|c|}
\hline \multicolumn{2}{|r|}{ Abo-Gharib } & $\begin{array}{c}\text { Triiodothyronine } \\
\text { (ng/ml) }\end{array}$ & $\begin{array}{c}\text { Thyroxine } \\
(\mu \mathrm{g} / \mathrm{dl})\end{array}$ & \begin{tabular}{|c|} 
Thyrotropin \\
(mIU/l)
\end{tabular} & $\begin{array}{c}\text { Serotonin } \\
(\mathrm{ng} / \mathrm{mL})\end{array}$ \\
\hline \multirow{2}{*}{ T3 } & Pearson Correlation & & -.213 & $-.315-$ & .220 \\
\hline & $\mathbf{P}$ & & .682 & .541 & .675 \\
\hline \multirow{2}{*}{$\mathbf{T 4}$} & Pearson Correlation & & & .228 & .187 \\
\hline & $\mathbf{P}$ & & & .661 & .723 \\
\hline \multirow{2}{*}{ TSH } & Pearson Correlation & & & & $-.201-$ \\
\hline & $\mathbf{P}$ & & & & \\
\hline
\end{tabular}

Table (4)

Correlation coefficients of the human serum serotonin in relation to thyroid hormones in Al-Jadria.

\begin{tabular}{|c|c|c|c|c|c|}
\hline \multicolumn{2}{|r|}{ Al-Jadria } & $\begin{array}{c}\text { Triiodothyronine } \\
(\mathrm{ng} / \mathrm{ml})\end{array}$ & $\begin{array}{c}\text { Thyroxine } \\
(\mu \mathrm{g} / \mathrm{dl})\end{array}$ & $\begin{array}{c}\text { Thyrotropin } \\
\text { (mIU/I) }\end{array}$ & $\begin{array}{c}\text { Serotonin } \\
(\mathrm{ng} / \mathrm{mL})\end{array}$ \\
\hline \multirow{2}{*}{ T3 } & Pearson Correlation & & .368 & $-.182-$ & $-.331-$ \\
\hline & $\mathbf{P}$ & & .471 & .727 & .522 \\
\hline \multirow{2}{*}{ T4 } & Pearson Correlation & & & .495 & $-.025-$ \\
\hline & $\mathbf{P}$ & & & .316 & .962 \\
\hline \multirow{2}{*}{ TSH } & Pearson Correlation & & & & .532 \\
\hline & $\mathbf{P}$ & & & & .277 \\
\hline
\end{tabular}

Evidence suggests that serotonin, a neurotransmitter strongly involved in depression, has also shown other studies that thyroid hormones and depressive symptoms are closely linked; some studies have also suggested that the risk of depression in serotonin in normal thyroid function is increased [ $\left.{ }^{8}\right]$.

In human beings, special in the both groups Al-Karradah and Abo-Gharib found serotonin levels are negatively correlated to TSH concentrations, therefore, empower the emission of TSH, the expansion of TSH would create an expansion in the generation of T3 and T4, having a tendency to decrease the serum level of TSH through criticism. This 'new' level of TSH is improperly high in connection to the expanded generation of T4; serotonin plasmatic levels are emphatically corresponded to $\mathrm{T} 3$, serotonin serum levels use to be lessened, our results were agreed with other study. [?]

Impacts of tentatively instigated thyroid states on mind serotonin system in human, in these examinations, 5-hydroxytryptamine
(5-HT, serotonin) the primary serotonin metabolite, were observed to be altogether lifted contrasted with euthyroid controls, other information have exhibited that neonatal hyperthyroidism disease instigated by every day utilization of T3 additionally brought about an expanded turnover of serotonin..$\left.^{7}\right]$

A cross-sectional relationship study in the United States revealed that, thyroxine (T4), and triiodothyronine (T3) were positively correlated with thyroid stimulating hormone (TSH)..$\left.^{10}\right]$

Right now, serum-based immunoassays procedures are accessible for measuring thyroid hormones thyroxine (T4) and triiodothyronine (T3), and also the pituitary thyroid stimulator, thyroglobulin ( $\mathrm{Tg}$ ) and thyrotropin TSH at present, and serotonin for three groups [Al-jadria group (control group), al-karradah group and abo-Gharib group most thyroid testing is performed on serum examples utilizing manual or computerized immunoassays utilizing particular counter acting agent reagents focusing on these 
ligands. Hence, strategies for distinguishing thyroid hormones estimation from semiquantitative systems, to more touchy ELISA. $\left[{ }^{11}\right]$

Based on our results, it can be ascertained that, in serotonin has obvious stimulation effects, serotonin can directly affect the forward movement of thyroid organs, thus serotonin would stimulate follicular response to thyrotropin and an elevated triiodothyronine and thyroxine versions showing a positive correlation between triiodothyronine and thyroxine and serotonin in the both group of Al-Karradah and abo-Gharib. $\left.{ }^{12}\right]$

\section{Conclusions}

In general al-karadah and Abo.Gharib populace, a negative associations were observed between the sera serotonin and thyroid stimulating hormones levels, and positive associations between Serotonin and T4 levels. There were significant positive relationships between serotonin and T3. The effect of terrorist operation on the environment in Iraq pollution in al-karadah and abo.Gharib populace may be causes to decrease thyroid hormone production. In the end we concluded that serotonin levels in the area of (Al-karadah, Abo-Gharib) pollutants areas were high as compared with the control (Al-jadria).

\section{References}

[1] Devashish M., Cong P., and Subhayu B., The Effects of Terror on International Air Passenger Transport: An Empirical Investigation. Federal Reserve Bank of St. Louis Research Division, 1-43, 2017.

[2] Dahr J., Burhan A., 'Iraq: War's legacy of cancer", Aljazeera "Someone must be held Accountable for the War in Iraq," in IraqThe Forgotten People Geneva International Centre for Justice, 2013.

[3] Elsayed S. A., Maram A., Fawzh A., Hend A., Jizayah A., Maha A., and Reem A., Effect of Water Pollution on Blood Elements in the Human Population of Hail. International Journal of Medical Research \& Health Sciences, 6(2), 43-48, 2017.

[4] Nele F., Maik P., Claire C., Betina H. T., Torben H., Henri W., Niels G., Tea S., Kathrin B., Oluf P., Matthias N., and Allan
L., Urinary metabolomics reveals glycemic and coffee associated signatures of thyroid function in two population-based cohorts. Journal pone, 12(3), 1-17, 2017.

[5] Bram G. J., Nelly D. S., Harry A. R., Narjes M., Wilfried G., Wouter L., Joris P., Charlotte V., Karen V., and Tim S. N., Fetal Thyroid Function, Birth Weight, and in Utero Exposure to Fine Particle Air Pollution: ABirth Cohort Study. Environmental Health Perspectives, 125, 699-705, 2017.

[6] Junhua L., and Feng L., The Role of Serotonin beyond the Central Nervous System during Embryogenesis, Frontiers in Cellular Neuroscience, 11(74), 1-7, 2017.

[7] Rahman MH., Ali MY., The Relationships between Thyroid Hormones and the Brain Serotonin (5-Ht) System and Mood: Of Synergy and Significance in the Adult Brain- A Review, Faridpur Medical College Journal, 9(2), 98-101, 2014.

[8] Satish KB., Monika R., Shalini S., Suresh Y., Nidhi V., Depression and thyroid function tests, Muller Journal of Medical sciences and Research, 6(1), 54-58, 2015.

[9] Mirella P. H., and Sami T. A., The Link between Thyroid Function and Depression, Hindawi Publishing Corporation Journal of Thyroid Research, 1-8, 2012.

[10] Xinwen D., Jin D., Yue Z., Jipeng G., Zhanju W., Mingqi L., Yunbo Z., and Xiaolin N., Effects of Long-Term In Vivo Exposure to Di-2-Ethylhexylphthalate on Thyroid Hormones and the TSH/TSHR Signaling Pathways in Wistar Rats. International Journal of environmental and Research and Public Health, 44, 1-14, 2017.

[11] Carole S., THYROID FUNCTION TESTS: ASSAY OF THYROID HORMONES AND RELATED SUBSTANCES, Thyroid Disease Manager, 1-104, 2017.

[12] Rosaria S., Vincenza L., Francesca V., Rosalia L., Antimo C. and Lorenzo V., Serotonin and thyroid gland in the lizard Podarcis sicula, Italian Journal of Zoology, 68(2), 95-99, 2009. 